\title{
ENTERPRISE LIABILITY, PUBLIC AND PRIVATE
}

\author{
WILLIAM F. BAXTER*
}

I find that I have difficulty in commenting on Professor Mashaw's paper. ${ }^{1}$ The difficulty stems, at least in part, from my uncertainty about what the paper, in its totality, should be understood to say. Mashaw states that the purpose of the paper is to examine the rationale for the official-immunity doctrine; ${ }^{2}$ and the paper does indeed hold up for our examination the several rationalizations for that doctrine that have been offered from time to time by various courts and commentators. ${ }^{3}$ With appropriate tentativeness Professor Mashaw offers several quite imaginative, additional rationalizations which-so far as I am aware-are original with him. ${ }^{4}$ But nowhere does the paper indicate whether the author finds these rationalizations persuasive.

Perhaps Professor Mashaw's caution merely reflects the fact that he remains uncertain whether the rationalizations are persuasive. This hypothesis about the author's ultimate state of mind seems quite plausible to me because I too find myself quite uncertain whether the rationalizations are persuasive.

I

\section{Criteria for Rules of Immunity}

While the author has my sympathy on that score, I find it rather more troublesome that the paper does not explicitly address itself at any point to the criteria which would enable one to judge whether the rationalizations were persuasive. I expect that in different intellectual forums, after appropriate debate, quite different criteria of persuasiveness would be agreed to. In this particular forum, I propose, the ultimate criterion should be maximization of a social-welfare function which has as its arguments (1) the magnitude of harm done to private parties by official transgressions, negatively signed; (2) the costs of enforcing sanctions that deter harm to private parties, negatively signed; and (3) some measure of the effectiveness of the government program

\footnotetext{
* Professor of Law, Stanford University School of Law.

1. This article is a commentary on Mashaw, Civil Liability of Government Officers: Property Rights and Official Accountability, LAw \& Contemp. Prob., Winter 1978, at 8. It was originally presented, in a slightly different form, at the Liberty Fund, Inc., Seminar on Civil Liability and Government Officials, administered by the Law and Economics Center of the University of Miami School of Law (April 15-17, 1977).--Ed.

2. Id. at 9 .

3. Id. at $14-22$.

4. Id. at 26-34.
} 
in the context of which the transgressions occur, positively signed.

The first two arguments of the welfare function are by no means easy to deal with, although they are perhaps no more difficult to deal with in the present context than in a wide variety of other legal contexts where they would be encountered-for example, in the context of the personal liability of corporate employees for transgressions committed in their employment. But it is the third argument in the welfare function, I believe, which constitutes the insurmountable barrier to a satisfactory analysis of the problem that has been set for us in this symposium.

To put the matter more concretely, and perhaps more simply, I think we should be asking three questions: (1) whether the official-immunity doctrine increases or decreases the harm caused to private parties by official transgressions; (2) whether it increases or decreases the social cost of reducing harmful transgressions with other sanctions; and (3) whether it increases or decreases the effective implementation of the government programs with which the transgressions are associated. If it decreases the first two and increases the third, most of us, I assume, would pronounce the immunity doctrine a good thing. If it increases the first two and decreases the third, most of us, conversely, would pronounce it a bad thing. If the changes which the immunity doctrine induces in these three variables conform to neither of these simple patterns, normative evaluation of the immunity doctrine becomes more complex: we would then have go on to inquire how much each of the individual arguments was altered; and further, we would have to agree on some unit in which to weigh tradeoffs between, for example, increases in the harm to private parties and increases in the effectiveness of the associated programs.

For me, as soon as the problem is seen in this light, its wholly unmanageable complexity becomes apparent. I recur to the fact that I said a moment ago that "most" of us would pronounce the immunity doctrine desirable if it moved all three of the variables in the direction which was prima facie desirable. Why would not all of us do so? Not all of us would, I suspect, because, with respect to any particular government program, not all of us would accept the premise that effective implementation was desirable. I, for example, would be willing to tolerate at least a slight increase in harm to private parties for the sake of less effective implementation of Interstate Commerce Commission motor-carrier regulation. ${ }^{5}$ Hence, I see the difficulty of evaluating government programs as one insurmountable barrier to an intellectually satisfying analysis of the sovereign-immunity doctrine. And, of course, the difficulty need not be as stark as in the instance I have picked: the difficulty would arise even if we could all agree that, on balance, the government program was useful rather than absolutely harmful; for even so, we would be

5. See generally A. Friedlaender, The Dilemma of Freight Transport Regulation 141-55, 163-66 (1969). 
hard put to reach agreement on how much we were willing to pay in terms of harm to private parties in exchange for a given improvement in implementation.

\section{II}

\section{The Private-Sector Analogy}

I think that some additional light can be thrown on the intractability of the official-immunity question by abandoning it for a moment and posing an analogous question set in the context of the private sector. Let us suppose that by some judicial quirk we were confronted with a rule which conferred immunity from civil liability on employees of industrial corporations with assets in excess of $\$ 10$ million. The question here, as in the actual public-sector case, would be: Is such immunity a good thing? At first glance it might seem that the appropriate avenue of analysis, if not the right answer, was clear in the private sector. We would start down that apparently appropriate avenue of analysis by observing that not all the social costs of the activities of the firms in question were brought home to the decisionmakers. Some of the costs would be left external to the firms. And we might move on to the tentative conclusion that too many resources were being devoted to the activity in question, and so forth, along familiar lines.

And yet a moment's further thought would show that we had gone too far too fast. The fact that the costs of harm to outsiders are not being transferred to employees of a firm does not mean that those costs are not being transferred to the firm itself. The rule of employee immunity which I hypothesized said nothing at all about the civil liability of the corporation. If the firm were subject to an appropriate rule of civil liability, then the managers of the firm would have appropriate incentives to take intracorporate measures to minimize the costs imposed upon the firm as a consequence of harm to outsiders. Indeed, those measures might go beyond the merely intracorporate and include suits by the firm against employees for indemnification, on the ground that their transgressions constituted breaches of their employment contracts. And even the purely intracorporate measures might be structured to have much the same financial impact on employees as suits by third parties would have had, had they been permitted.

In short, even in the context of the private sector, where clearer avenues of analysis are opened by assumptions about profit maximization and freemarket evaluation of output, we would be unable to say anything useful about a rule of employee immunity unless we were to conduct a simultaneous inquiry into the rules of enterprise liability.

And I suggest, by this analogy, that the same is true in the context of the public sector. Only the conjunction of official immunity with sovereign immunity can lead us to any confident conclusion about the social desirability of the official-immunity rule; and this would be true even if we were able to deal 
more confidently than in fact we can with the social value of the various outputs of governmental enterprises.

In order to make a minor degree of progress with the analogy before us, I make some very heroic assumptions: (1) All government programs are, at least on balance, marginally desirable; (2) the incentives of government managers induce them to minimize the costs of rendering a service and to expand or contract their output until the marginal costs of services are roughly commensurate with their marginal utility to taxpayers; (3) notwithstanding the continued vitality in some contexts of the historical doctrine of sovereign immunity, the waivers of that doctrine contained in the Federal Tort Claims Act, ${ }^{6}$ the Court of Claims Act, ${ }^{7}$ and various other specific statutes have in their totality the consequence that the government enterprise as a whole is subject to civil liability in the overwhelming preponderance, if not in all, of the appropriate contexts.

If these assumptions are indulged, heroic though they are, the problem of official immunity becomes roughly analogous to the hypothetical conditions of employee immunity which I posited earlier. This laborious process of converting an intractable problem into a merely hypothetical problem may hardly seem worthwhile. Yet I suggest that it may take us a bit further with the analysis of the former problem.

It is my general impression that the industrial and legal contexts in which the private sector functions resemble closely my hypothetical rules of employee immunity coupled with enterprise liability. When third parties are damaged by employee transgressions, both the employee and the corporate employer are available as defendants unless the employee was acting outside the scope of his employment. ${ }^{8}$ If the employee was acting out of personal malice, that circumstance alone will often, although not always, take his conduct outside the scope of his employment, in which case only the employee is liable.$^{9}$ If both employee and corporate employer are available as defendants, the third party will almost invariably sue the corporate employer and will not sue the employee. Even when recovery is won from the corporate employer, the employer will only on the most extraordinary occasions resort to judicial proceedings against the employee for indemnification. Indeed, the express or implied terms of employment contracts far more often call for employer indemnification of employees, should they be held liable individually. Whatever other sanctions

\footnotetext{
6. 28 U.S.C. $\S \S 2671-80(1970 \&$ Supp. V 1975).

7. 28 U.S.C. \$ 1491 (1970 \& Supp. V 1975).

8. See generally Restatement (Second) of Agency $\$$ 219-49 (1958); W. Prosser, Handbook of The Law of TORTS 460-67 (4th ed. 1971); 2 F. Harper \& F. James, JR., The Law of Torts 1374-94 (1956).

9. See Restatement (Second) of Agency \& 235, illustration 2 (1958); W. Prosser, supra note 8, at 465; F. HARPER \& F. JAMES, JR., supra note 8, at 1391-92.
} 
the employer may invoke are imposed through intracorporate means, such as discharge, reassignment, censure, or reduction in pay.

This pattern is not dissimilar to the pattern we see in government. With crude generality one can say of both sectors that the employee, and only the employee, is liable when the transgression is a product of his personal malice rather than an attempt to implement the policies of the employer; and in other cases the employer, and only the employer, is in fact held liable. In both sectors the employer currently has rights of indemnification against the employee and could, by contract, expand his rights of indemnification to embrace a large fraction of all the imaginable instances of vicarious employer liability; yet in neither sector do we find employers resorting to judicial damage claims to enforce even existing rights of indemnification; and we observe no general pattern of contractual expansion of the right to indemnification.

To me this pattern suggests quite strongly that managers in bureaucratic contexts, be they public or private, do not find it cost-effective to impose pecuniary responsibility for harm to third parties on individual employees. And it is not difficult to formulate intuitively appealing explanations of why that is so: Pecuniary responsibility on the part of employees leads to internal inefficiency, not because employee behavior is unresponsive to the prospect of such liability but because it is too responsive. Liability induces the employee to adopt behavior that is suboptimal from the standpoint of the employer. Pecuniary responsibility forces employees to choose between protecting their own purses and executing the programs of their employers with zeal and imagination. We should not be surprised to find that employees who face such a choice strike a different balance than would those who had to bear both the costs of harm to outsiders and the costs of ineffective implementation, and who, therefore, had an incentive to equalize the two types of cost at the margin.

\section{III}

\section{Differences Between Public and Private Sectors}

Let me now turn from my emphasis upon the similarities between the private and public sectors and attempt to identify some critical differences. One of the most intriguing differences is the immunity from suit conferred, not upon government employees, but upon the government as employer by the so-called discretionary exception ${ }^{10}$ in the Federal Tort Claims Act.

To highlight the difference $I$ have in mind, let me posit two cases. In the first, Lockheed decides to build a small, relatively low-cost propjet aircraft, which it intends to sell to other corporations for business travel. In the course of engineering design the question arises whether the plane should be equipped with de-icing apparatus. After well-documented internal delibera-

10. 28 U.S.C. $§ 2680$ (1970 \& Supp. V 1975) 
tions a decision is reached, because of fuel and construction costs, not to install de-icers. Subsequently, when the plane is being flight-tested in southern California, extraordinary and unforseeable high-altitude weather conditions cause ice to form; the plane crashes into a residential area, killing a number of people and doing extensive property damage. In the second case the facts are the same except that the plane is a military plane, all design decisions are made in the Pentagon, and the ultimate decision not to install the de-icer is made by the Assistant Secretary of the Air Force on the ground that the extra weight will reduce the plane's range and impair its military-reconnaissance effectiveness.

In the forseeable civil suits charging the plane's designers with negligence, judgment against Lockheed is a probable outcome in the first case, whereas judgment against the Government would almost certainly be precluded on the ground that the design decision was a discretionary act under the terms of the Tort Claims Act.

In the private suits the court would review and, in substance, second-guess the wisdom of the decision to omit the de-icer. Testimony about the cost and weight of de-icers and about the impact of that weight on fuel consumption would be admissible, and probably critical. It is clear that a judicial tribunal is not well suited to making engineering-economic decisions of this kind. And yet the private controversy would come to the court with that decision as its root. One can imagine that some courts, at some times and places, might try to compensate for their perceived institutional inappropriateness by subjecting the design decision to a test of reasonableness, or even to a test of good faith; but to a greater or lesser degree the courts would have to second-guess the decision.

The exception for discretionary acts in the Federal Tort Claims Act constitutes recognition of the inappropriateness of judicial tribunals as secondguessers of policy decisions for which primary responsibility has been lodged elsewhere in government, presumably in more competent hands. At bottom the difference between the scope of private-enterprise liability and governmententerprise liability to which the exception gives rise reflects a judgment that some neutral-that is, governmental-tribunal must second-guess Lockheed's decision but not the Government's, because Lockheed cannot be relied upon to take into account adequately the interests of potential third-party victims whereas government decisionmakers can be relied upon to do so, at least to a greater extent-to an extent sufficient to tip the balance against secondguessing by an institutionally unsuited judiciary.

In the case I have posited one might question the desirability of the exception for discretionary acts, pursuing the usual lines of argument about the desirability of internalizing all social costs. But I selected this case because I wanted to be able to frame a very close private analogy, not because the case illustrates persuasively the propriety of the discretionary exception. As one 
moves farther and farther away from quasi-proprietary activities, like designing aircraft, toward purely governmental rulemaking and legislation, the argument against judicial second-guessing of considered policy decisions made in other parts of government becomes stronger. It becomes, in the context of government-enterprise liability, closely analogous to what Professor Mashaw refers to as the cause-of-action problem in the context of the officialimmunity doctrine. ${ }^{11}$ At some point along that spectrum, I suppose all of us would agree, judicially administered damage remedies cease to be appropriate, because they constitute a transfer to the judiciary of choices we think inappropriate to the judiciary. And if those choices are inappropriate to the judiciary at the enterprise-liability level, then they are inappropriate at the officialliability level as well.

In my opinion, a major weakness in Professor Mashaw's paper is that he assumes the desirability of, and suggests methods for, expanding the judiciary's role in second-guessing government policy decisions without analyzing critically when it is inappropriate to make the judiciary, rather than another branch of government, the locus of decisionmaking.

The final difference $I$ wish to note between private enterprises and governmental enterprises is the following: Apart from the desirability of compensating injured victims-an important theme in tort liability but one which Professor Mashaw sets aside in the opening paragraphs of his paper ${ }^{12}$ and which I, too, therefore leave to one side-the reason for imposing liability on private enterprise for harm to third parties is that a firm is better able than its victims to minimize the sum of production costs and the costs of such harm. If a firm bears the costs of harm to third parties, the firm will find it profit-maximizing to reduce the magnitude of harm by changing its inputs, internal processes, or both to the extent that it can do so at a cost less than the reduction in harm. And to the extent that such adaptations are not possible the costs of remaining harms, if imposed on the firm, will be reflected in the price of its outputs, causing a reduction in output, perhaps to zero. This socially optimal reduction in output, which occurs without regard to whether adaptation is cheap or infinitely costly, occurs because the firm faces a demand curve which is, to some degree, elastic.

When one turns to the question of government-enterprise liability, one must recognize that there is far less assurance that either intra-enterprise adaptation or output reduction will occur: in many instances output price is zero; in others price will bear no specific relationship to cost; incentives for cost minimization appear to be weak; and empire-building may constitute the dominant institutional motivation.

Nevertheless, Professor Mashaw's suggestion that something might be

11. Mashaw, supra note 1 , at 29-33.

12. Id. at 9 . 
gained from imposing enterprise liability, not on the United States Treasury in general, but on individual agency budgets is ingenious and deserves a good deal more thought. It is at least conceivable that cost sensitivity would be enhanced by a system of liability along those lines; and if that is true, the social utility of imposing liability would be enhanced.

But with only such minor qualifications as may be appropriate in view of this last point, realism requires that damage remedies against the government enterprise be viewed primarily as compensation mechanisms rather than behavior modifiers. Hence Mashaw's decision to ignore compensation in this context seems to me to ignore the most pertinent consideration. And to the limited extent that behavior modification is a realistic possibility one can say little that is useful about official liability unless it is viewed in the immediate context of enterprise liability. Viewed outside that context, official liability is analogous to one-handed clapping. 